Historia Slavorum Occidentis

2018, nr 3 (18)

ISSN 2084-1213

DOI: $10.15804 /$ hso 180307

JaKub Muchowski (Kraków)

\title{
Realizm i modernizm, sprawcy i ofiary. Odpowiedź na komentarz Macieja Bugajewskiego ${ }^{1}$
}

Bardzo się ucieszyłem, że autorytet w dziedzinie teorii historii Maciej Bugajewski skomentował moją książkę o refleksji teoretycznej Haydena White’a. Jestem mu wdzięczny za uważną lekturę i szczodre uwagi. Jego wypowiedź składa się z dwóch części: omówienia pracy i propozycji frapującej wykładni poruszanej w niej problematyki ujmowanej przez Haydena White’a przy użyciu pojęć „zdarzenia modernistycznego" i „realizmu modernistycznego”. W pierwszej Bugajewski uważnie odczytuje tekst przedstawiając kluczowe składniki pracy. Swoje kroki stawia zgodnie z moimi zamysłami i życzliwie odnosi się do przygotowanej przeze mnie oferty opracowania pisarstwa White’a. W tej części artykułu zgłasza jedno zastrzeżenie wobec mojego tekstu, nie będę więc jej odtwarzał w całości, a odniosę się tylko do zgłoszonej przez niego wątpliwości.

\section{Filozofia i teoria literatury}

Jego zdaniem na krytyczny komentarz zasługuje jedno z ogólnych założeń mojej pracy stwierdzające, że ważnym osiągnięciem intelektualnym White’a było prze-

\footnotetext{
1 Tekst ten jest odpowiedzią na polemikę Macieja Bugajewskiego (M. Bugajewski, Dialektyka realizmów historiograficznych. Lektura książi Jakuba Muchowskiego, Polityka pisarstwa historycznego. Refleksja teoretyczna Haydena White'a, Historia Slavorum Occidentis 11 (2016), nr 2, s. 266-276) z moją książką (J. Muchowski, Polityka pisarstwa historycznego. Refleksja teoretyczna Haydena Whitéa, Warszawa-Toruń 2015).
} 
niesienie teoretycznej dyskusji nad historią z pola filozofii na pole teorii literatury. Zastrzeżenia Bugajewskiego budzi wynikające z tej wypowiedzi silne rozróżnienie teorii literatury i filozofii. Ta pierwsza jest bowiem jego zdaniem subdziedziną refleksji filozoficznej, z którą łączy ją metodologia i tradycje, do których się odwołuje. Dodaje, że podział pracy naukowej na fakultety nie wpływa znacząco na związki teorii literatury i filozofii. Bugajewski zauważa zarazem, że sam White nie jest postrzegany jako filozof i sam w ten sposób się nie określa, wyjaśnia to jednak brakiem zainteresowania filozofią analityczną, która jest domyślnym sposobem uprawiania filozofii w kręgu angloamerykańskim. Podsumowując swoje uwagi, pyta, dlaczego White nie może być nazywany filozofem, skoro tym mianem określamy np. Michela Foucaulta.

Nie potrafię odpowiedzieć na pytanie, jaka dokładnie jest relacja między filozofią a teorią literatury, w tym, czy ta druga jest subdziedziną filozofii, czy też nie. Nie jestem też zwolennikiem silnego zakreślania i patrolowania granic dyscyplin. Uważam jednak, że warto ujmować praktykę teoretyczną White’a (mniej więcej od początku lat siedemdziesiątych) i jej konsekwencje przy pomocy formuly „przeniesienia refleksji nad historią z filozofii w pole teorii literatury”. Trafnie oddaje ona współudział White'a w procesie zdominowania humanistyki drugiej połowy XX w. przez dyskurs badań literackich, w tym refleksji nad historią, przez teorię literatury. Zwrot ten animowała myśl strukturalistyczna współtworzona w przeważającej mierze przez językoznawców, literaturoznawców i etnografów. W zmianie tej uczestniczyli też filozofowie (np. Jacques Derrida, Gilles Deleuze i Louis Althusser), których myślenie było jednak inspirowane w większej mierze przez nowe treści oferowane przez strukturalizm, a później poststrukturalizm niż tradycję filozoficzną. Nowy słownik refleksji teoretycznej w humanistyce był wypracowywany w zasadniczej mierze nie w oparciu o zasób filozofii, ale trzech wspomnianych dziedzin² .

Uważam, że postrzeganie napędzanych przez propozycje White zmian w refleksji nad historią lat siedemdziesiątych jako wydarzenia dyskursywnego, w ramach którego centrum praktyki teoretycznej staje się teoria literatury, pozwala lepiej je zrozumieć. White nie inspiruje się pracami analitycznych filozofów historii (np. Patricka Gardinera, Williama Walsha, Waltera Bryce’a Galliego, Williama H. Draya, Arthura C. Danto, Mortona White’a) lub filozofów języka (np. Richarda Rorty'iego, Johna Searle’a, J.L. Austina), którzy są ważni dla prac Franka Ankersmita czy J.G.A. Pococka i Quentina Skinnera. Filozofia kontynentalna - poza Karolem Marksem,

2 Por. K.L. Klein, From History to Theory, Berkeley 2011, s. 35-58; D. Bachmann-Medick, Cultural Turns. Nowe kierunki w naukach o kulturze, przeł. K. Krzemieniowa, Warszawa 2012, passim. 
Fryderykiem Nietzsche i Walterem Benjaminem - jest przedmiotem jego uwagi jako badacza zajmującego się historią intelektualną. Swoją refleksję teoretyczną opiera bowiem przede wszystkim na pracach Romana Jakobsona, Rolanda Barthesa, Northrope'a Frye, Ericha Auerbacha, Claude'a Levis-Straussa (tylko okazjonalnie badacza literatury) i Michela Foucault, z których jedynie ten ostatni bywa nazywany filozofem. Prace samego White’a były zaś inspiracją dla takich badaczy jak Linda Orr, Sande Cohen, Hans Kellner, Ann Rigney, James M. Mellard, Lionel Gossman, Larry E. Shiner, z których tylko ten ostatni pracował na wydziale filozofii.

Taktycznie przyjęty przeze mnie podział na teorię literatury i filozofię ma jeszcze jedno ważne uzasadnienie. Steruje on bowiem wypowiedziami komentatorów prac White'a. W zdecydowany i świadomy sposób posługuje się nim Ankersmit $\mathrm{w}$ ważnym artykule o pożytkach korzystania w refleksji nad historią z filozofii języka i szkodliwości sięgania w tym polu po teorię literatury ${ }^{3}$. U pozostałych symptomem pracy owego podziału w ich myśleniu jest zaskakująco niewiele omówień pisarstwa Whitéa osadzających je w kontekście teorii literatury i często łączących je z tradycją filozoficzną (ostatnio z egzystencjalizmem ${ }^{4}$ ). Buduje to wrażenie, że w środowisku teoretyków istotne praktyki i idee omawia się poprzez odniesienie ich do tradycji filozoficznej, do której jednak teoria literatury nie jest zaliczana.

\section{Doświadczenie modernistyczne}

W drugiej części komentarza Bugajewski oferuje autorską rozbudowaną interpretację jednej z nośnych propozycji White’a formułowanej od lat dziewięćdziesiątych. Pracował on wówczas z pojęciami „zdarzenia modernistycznego” i „realizmu modernistycznego" dla ujęcia problemu przedstawienia w pisarstwie historycznym katastrof dziejowych XX i XXI w., a zwłaszcza Holokaustu. Skomentowanie tekstów Whitéa, w których przedstawia swoje propozycje - co zgodnie odnotowujemy z recenzentem - napotyka na trudności. Jego uwagi są niepełne i rozproszone po wielu artykułach pisanych na przestrzeni ponad 20 lat, co sprawia, że są niejednoznaczne i rodzą wiele pytań.

3 F. Ankersmit, Zwrot lingwistyczny: teoria literatury a teoria historii, przeł. M. Zapędowska, [w: ] tenże, Narracja, reprezentacja, doświadczenie. Studia z teorii historiografii, red. i wstęp E. Domańska, Kraków 2004, s. 115-129.

4 Np. R. Doran, Choosing the Past: Hayden White and the Philosophy of History, [w: ] Philosophy of History After Hayden White, ed. R. Doran, London 2013, s. 1-33; P. Herman, Hayden White. The Historical Imagination, Cambridge-Malden 2011. 
Niejasne, jak zaznacza Bugajewski, są kwestie podstawowe. Prace White’a nie dostarczają bowiem klarownych rozstrzygnięć dotyczących logicznej kolejności między nowoczesnością czy nowym dzianiem się, „zdarzeniami modernistycznymi”, ich (modernistycznym) doświadczeniem i artykulacją tego doświadczenia w dyskursie $\mathrm{w}$ formie wypowiedzi modernistycznej czy „realizmu modernistycznego”. Trudno precyzyjnie określić, co jest najpierw, a co później, co jest pierwotne, a co wtórne, co jest bodźcem, a co reakcją.

Zarazem, co trafnie dostrzega recenzent, White wyraźnie zaznacza, że zdarzenie modernistyczne znajduje się po stronie reakcji na nowe dzianie się. Można się domyślać, że dlatego White nazywa je zdarzeniem modernistycznym, a nie zdarzeniem nowoczesnym, gdyż odwołuje się do utartej formuły mówiącej o modernizmie jako kulturowej odpowiedzi na udział w świecie nowoczesności ${ }^{5}$. W książce podkreślam, że White'owskie „zdarzenie modernistyczne” jest sposobem dyskursywnego ujęcia nowej klasy zjawisk, przy czym ich uchwycenie to zarazem ich konstruowanie. Rozpoznanie nowoczesnych zjawisk następowało w toku wyłaniania się i rozrostu modernizmu, ale on sam rozwijał się jako odpowiedź na nowe dzianie się (s. 159).

Duży kłopot sprawia też pojęcie doświadczenia. W zdominowanych przez strukturalizm latach siedemdziesiątych unikano tego terminu, gdyż miało ono sugerować możliwość bezpośredniego kontaktu z rzeczywistością. White nie posługiwał się nim jednak również w kolejnych dekadach, gdy pełniło ono w humanistyce pierwszoplanową rolę w debacie nad przedstawieniem Holokaustu i krytyce strukturalizmu. Co prawda, samo słowo pojawia się w jego tekstach, ale nie zostaje nawet skrótowo skomentowane i nie wiadomo, jak należy je rozumieć.

Bugajewski jest jednak przekonany, że warto uporządkować refleksje White’a przy użyciu tego pojęcia. Zastrzega, że uznaje wykładnię refleksji teoretycznej White’a, która eksponuje jego konstruktywistyczną perspektywę myślenia, w tym podkreślanie kreacyjnych elementów interpretacji historycznej sterowane wyborami etycznymi historyka. W swojej książce opisuję przesunięcie w teoretycznej refleksji White’a lat osiemdziesiątych i dziewięćdziesiątych, w toku którego odchodził on od mocnego stanowiska konstruktywistycznego. Bugajewski uważa, że zmiana ta mogła sięgać dalej niż ja to przedstawiam. Zdaniem Bugajewskiego liczne odniesienia do prac Barthesa i Derridy dotyczących pisarstwa nieprzechodniego i strony zwrotnej, które zainicjowały zwrot poststrukturalny, pozwalają interpretatorowi wypowiedzi White’a sformułować bardziej klarowne twierdzenia dotyczące relacji między nowo-

5 Np.J.F. Lyotard, Kondycja ponowoczesna, przeł. M. Kowalska, J. Migasiński, Warszawa 1997, s. 25. 
czesną rzeczywistością, zdarzeniem modernistycznym i realizmem modernistycznym. Proponuje zatem ująć ją przy użyciu pojęcia doświadczenia, które ma uchwycić procesy rozgrywające się w sferze pomiędzy dzianiem się a dyskursem, który się do niego odnosi. Doświadczenie tak rozumiane jest reakcją na zajścia, która artykułuje się w dyskursie. Włączenie tego pojęcia do myślenia o reprezentacji przeszłości, jak wyjaśnia Bugajewski, ma służyć uwzględnieniu również tego, co należy do porządku dziejów, a nie tylko wewnętrznej dynamiki rozrostu pisarstwa historycznego. W ułożonej przez niego sekwencji zjawisk najpierw przebiegają modernistyczne zdarzenia, następnie wyłania się ich doświadczenie, które w kolejnym kroku jest opracowywane $\mathrm{w}$ dyskursie przybierając postać realizmu modernistycznego. W związku z tą propozycją sugeruje również, że powinienem w odwrotnym porządku omówić pojęcia realizmu modernistycznego i zdarzenia modernistycznego, tzn. najpierw to drugie.

Z perspektywy prac White’a można zgłosić kilka uwag do tej oferty. Wątpliwości budzi zasugerowana w niej linearność związku między trzema elementami, relacje pomiędzy nimi mają bowiem charakter dwustronny, a logiczna kolejność następujących po sobie akcji i reakcji nie powinna sugerować, że to, co zajmuje wcześniejszą pozycję, decyduje o tym, co następuje później. Spójny z refleksją White’a będzie pogląd, że krążące w danej przestrzeni społecznej dyskursy wytwarzają dzieje i kształtują ich doświadczenie, które podlega dalszej obróbce kulturowej w procesie artykulacji. Co więcej, oddziaływanie dominujących wzorców, narracji i figur wypowiedzi może mieć większą siłę niż bodźce płynące ze sfery dziania się. W swojej książce celowo omówiłem najpierw realizm modernistyczny, a później zdarzenie modernistyczne (s. 146-163), gdyż taka kolejność sprawiała, że bardziej wyrazisty stawał się zamysł White’a. Stąd odwrócenie zdroworozsądkowej kolejności sugerującej, że najpierw się coś wydarza, a następnie wywołuje reakcję.

Jak odnotował Bugajewski, White wskazywał, że freudowskie ujęcie traumy warto wykorzystać do omówienia budowy zdarzenia modernistycznego. Amerykański teoretyk wydawał się też sugerować, że trauma jest modernistycznym sposobem ujęcia nowoczesnej rzeczywistości. Do pojęcia „traumy” White’a przyciągnęło kilka jego elementów. Po pierwsze, termin „trauma” służy uchwyceniu reakcji na wydarzenie, a nie ujęciu jego samego. Po drugie, opisuje indywidualny lub zbiorowy tryb reakcji, w ramach którego zajścia nie poddają się opracowaniu przy użyciu obowiązujących systemów znaczeniowych (w tym kluczowych wyobrażeń na temat własnej tożsamości), a tym samym destabilizują je i niszczą oraz napędzają poszukiwanie nowych. Wreszcie, po trzecie, reagujący podmiot nie posiada wiedzy, a tym samym kontroli nad tym, co mu się przydarza i nad samym sobą oraz nad narzędziami kul- 
turowymi (językowymi, wizualnymi, performatywnymi), które służą mu do wytwarzania takiej wiedzy.

Podobnie do wypowiedzi modernistycznych, opis traumy mówi o rozbitych i słabych podmiotach oraz niestabilnej i niezrozumiałej rzeczywistości. Razem z opisywanymi przez Barthesa i Derridę pisarstwem nieprzechodnim i wypowiedziami w stronie zwrotnej trauma Freuda jest modernistyczną odpowiedzią na nowoczesną rzeczywistość zakładającą nie tylko niezdolność do zapanowania nad dyskursem (co obecne było w myśleniu White’a od Metahistory), ale też wagę wpływu czynników pozajęzykowych. White nie podjął się jednak próby rozpoznania tych ostatnich, koncentrując się na ich wpływie (przede wszystkim destruktywnym) na artykulację relacji nowoczesnych ludzi do nowoczesności. Trudno powiedzieć, czy z oferty współczesnej humanistyki zajmującej się tym polem badań wybrałby na przykład rzeczy czy może afekty ${ }^{6}$. Nie spróbuję dalej rozbudowywać opisu rezultatu połączenia pojęcia doświadczenia z propozycjami White’a. Zostawił on za mało wskazówek podpowiadających, w którą stronę ta interpretacja miałby pójść.

\section{Modernistyczni sprawca, ofiary i inni}

Sam Bugajewski w komentarzu stara się rozbudować omówienie natury nowoczesnego doświadczenia i formuluje bardziej zdecydowane rozstrzygnięcia rekonfigurujące propozycje płynące z refleksji White’a. Podążając za Whitem stwierdzającym, że dwudziestowieczna rzeczywistość to dystopia globalnego kapitalizmu, dodaje, że generuje ona modernistyczne wydarzenia, na które reakcją jest modernistyczne doświadczenie. Skoro dystopia to porządek, który niesie zagrożenia dla jednostek i grup, to wytwarzane przez nią wydarzenia modernistyczne są niebezpiecznymi zajściami, a udziałem ich uczestników jest doświadczanie cierpienia. Zależność tę zatem Bugajewski utożsamia z opozycją sprawcy i ofiary: modernistyczne wydarzenie byłoby rezultatem akcji sprawcy, a doświadczenie modernistyczne - udziałem ofiary. Nadaje jej tym samym konkretny, etyczny wymiar, co jak słusznie podkreśla, jest zgodne z podejściem Whitea, dla którego stawką refleksji teoretycznej nad historią było budowanie wolnego, sprawiedliwego i równego świata.

Rozwijając swoją myśl Bugajewski proponuje, aby doświadczenia ofiary ujmować przy użyciu realizmu modernistycznego, natomiast dystopię, czyli sprawcę wy-

6 Zob. np. G. Harman, Traktat o przedmiotach, przeł. M. Rychter, Warszawa 2013; A. Dauksza, Afektywny modernizm. Nowoczesna literatura polska w interpretacji relacyjnej, Warszawa 2017. 
wołującego owo doświadczenie, w realizmie dziewiętnastowiecznym. Takie rozwiązanie podsuwają opisane przez White’a cechy z jednej strony dystopii, z drugiej zaś wypowiedzi modernistycznej. Ta pierwsza jest rzeczywistością wytworzoną przez współczesną naukę, zaawansowaną technologię oraz najwydajniejsze procedury zarządzania wykorzystywane przez aparaty władzy politycznej, ekonomicznej czy społecznej. Ta druga zaś konstruuje obraz świata składający się ze zdarzeń, które trudno zidentyfikować (np. określić ich granice), ustalić ich relację z kontekstem, łączyć je w szeregi, hierarchizować i porządkować w narracje, oraz z podmiotów o złożonej tożsamości i słabej sprawczości, gdyż wiązanych skomplikowanymi sieciami zależności.

White uważa, że pisarstwo modernistyczne jest trafnym trybem artykulacji tak omówionej dystopii, co wydaje się Bugajewskiemu zaskakujące. Dlaczego bowiem efektywne, naukowe, racjonalne, wyrafinowane techniczne praktyki ujmować przy użyciu technik przedstawienia wytwarzających obraz działań, które są tylko częściowo zrozumiałe, nie podlegają pełnej kontroli i mogą mieć nieprzewidywalne konsekwencje. Czy nie należałoby raczej, pyta Bugajewski, posłużyć się opozycją akcji i reakcji, sprawcy i ofiary, a następnie zawęzić zastosowanie pisarstwa modernistycznego do uchwycenia doświadczenia dystopii przez jej ofiary? To bowiem ich udziałem jest dezorientacja, poczucie przytłoczenia i braku kontroli oraz niepewność przyszłości. Samo działanie maszyny dystopijnej, sugeruje Bugajewski, należałoby analogicznie artykułować przy pomocy realizmu przedmodernistycznego. Historiografia czasów najnowszych byłby zatem dyskursem dwojakim, pękniętym, kierującym swoją uwagę w stronę sprawców i ofiar oraz ujmującym te dwie pozycje przy użyciu dwóch trybów pisarskich, modernistycznego i przedmodernistycznego.

Powiązanie trybów wypowiedzi ( w tym wypadku historiograficznej) z pozycją w przestrzeni dziania się, która ma być przez nie artykułowana, to bardzo inspirujący pomysł. Zwłaszcza że zbiór pozycji można rozszerzyć, jak sugeruje dyskusja wokół propozycji Raula Hilberga ${ }^{7}$, w której rozpoznaje on kilka grup uczestników Holokaustu - zdarzenia modernistycznego par excellence. Opozycję sprawców i ofiar Hilberg uzupełnia o pojemną kategorię bystander (w polskim przekładzie „świadek”), a także wewnętrznie różnicuje te trzy podstawowe pozycje. Polskich badaczy najbardziej przyciąga właśnie pozycja bystandera, gdyż najtrafniej opisuje usytuowanie polskiego społeczeństwa w czasie Zagłady. Hilberg dzieli ją na m.in. na beneficjen-

7 R. Hilberg, Sprawcy, ofiary, świadkowie: zagłada Żydów 1933-1945, przel. J. Giebultowski, Warszawa 2007. 
tów, obserwatorów, posłańców i ratujących. Polscy uczestnicy debaty dodają kolejne figury: ułatwiaczy ${ }^{8}$, „pomocników śmierci”, obserwatorów uczestniczących ${ }^{10} \mathrm{czy}$ postronnych ${ }^{11}$. Wartym uwagi wydaje się pytanie, jaka forma wypowiedzi najczęściej, a także najklarowniej artykułuje to usytuowanie.

Zarazem jednak próby łączenia poetyk wypowiedzi z pozycjami podmiotów dziania się (niekoniecznie ludzkimi) obarczone są dużym ryzykiem. W swojej książce odnotowałem ujęcia łączące modernizm z faszyzmem ${ }^{12}$, wysuwane przez György Lukácsa i rozwijane przez kontynuatorów jego myśli, takich jak Fredric Jameson w swych wczesnych pracach (s. 138-140), czy realizm z konserwatyzmem (liberalnym lub totalitarnym) formułowane przez środowisko Tel Quel (s. 138-139), a także Waltera Benjamina (s. 197-200). Wspomniany Jameson w swych późniejszych tekstach przestrzegał przed myśleniem wiążącym formy wypowiedzi z pozycjami w porządku wywarzanym przez określoną formację społeczno-polityczną (s. 111-113), krytycznie odnosząc się również do kilku propozycji White’a, w których ten ostatni przypisywał stylom wypowiedzi stałe znaczenie ideologiczne (np. w teorii stylów historiograficznych w Metahistory).

Moje główne zastrzeżenie wobec intuicji Bugajewskiego ma jednak inny charakter. Uważam, że realizm przedmodernistyczny nie jest efektywnym środkiem opisu wskazanego sprawcy rzeczywistości XX i XXI w., czyli dystopii globalnego kapitalizmu. Realizm dziewiętnastowieczny - jak rozumiem o ten typ realizmu tu chodzi - dostarcza zdroworozsądkowych, uporządkowanych w liniowe łańcuchy przyczyno-skutkowe, jednoznacznych przedstawień rzeczywistości i uchwycenie nowego dziania przy jego użyciu nie uwzględni nowości, paradoksalności, wieloznaczności

8 Zob. J.T. Gross, Sprawcy, ofiary i inni, Zagłada Żydów 2014, nr 10 (Jan Tomasz Gross proponuje „ułatwiaczy” za: Mary Fulbrook, A Small Town near Auschwitz: Ordinary Nazis and the Holocaust, Oxford 2012).

9 Frazę Czesława Miłosza z wiersza „Biedny chrześcijanin patrzy na getto” (1943) przywołuje R. Sendyka w Poświadek, przeciw-postronny i (niczyja) trauma, Widok. Teorie i Praktyki Kultury Wizualnej 18 (2017), s. 5.

10 Zob. E. Janicka, Pamięć przyswojona. Koncepcja polskiego doświadczenia zagłady Żydów jako traumy zbiorowej w świetle rewizji kategorii świadka, Studia Litteraria et Historica 3-4 (2014/2015), s. $148-226$.

11 Zob. G. Niziołek, Polski teatr Zagłady, Warszawa 2013, s. 49; R. Sendka, dz. cyt., s. 5-10.

12 Na połączenie takie wskazał też Carlo Ginzburg w sławnej krytyce argumentacji Whitéa dotyczącej ujęcia Holokaustu przy użyciu technik modernistycznych. Zob. C. Ginzburg, Just One Witness, [w: ] Probing the Limits of Representation. Nazizm and the "Final Solution”, red. S. Friedlander, Cambridge-London 1992, s. 82-96. 
i złożoności tej formacji. Podobnie jak White sądzę, że niezależnie od tego, czy historyk chce skupić się na opracowaniu działania maszyny społecznej globalnego kapitalizmu czy doświadczeniu jego ofiar, może z dużym powodzeniem korzystać z poetyki modernistycznej. Uzasadniając swoją wątpliwość, wyjdę jednak w pewnej mierze poza ofertę pisarstwa White'a.

Sądzę bowiem, że efektywność zastosowania wypowiedzi modernistycznej do uchwycenia współczesnej dystopii potwierdzają m.in. rezultaty pracy współczesnych historyków i filozofów zajmujących się dziejami kapitalizmu. W książce sprzed kilku lat Jan Swianiewicz ${ }^{13}$ omówił trzy dwudziestowieczne propozycję ujęcia kapitalizmu jako przedmiotu badania - Fernanda Braudela, Immanuela Wallersteina i Deleuze’a. Projektowany przez nich obiekt można opisać w skrócie jako wirus lub widmo, gdyż nadbudowuje się nad poziomami rzeczywistości gospodarczej wchodząc $\mathrm{z}$ nimi w różnorakie interakcje, gnieździ się w porach dawnych społeczeństw albo nawiedza wszelkie formy społeczne. Jest elementem rzeczywistości historycznej rozpatrywanej przez trzech badaczy jako maszyna wiążąca w trudno uchwytną całość rozmaite trwania czy porządki (m.in. ekonomiczny, kulturowy, społeczny, polityczny) o ograniczonej autonomii i odrębnej czasowości, połączone zmienną siecią wielokierunkowych relacji, których pracą rządzą możliwe do zidentyfikowania, lecz nietrwałe prawidłowości. Działające w nich podmioty są rozumiane jako niestałe, składające się z zastanego materiału i przypadkowe wytwory określonych warunków. Nie znajdują się w centrum rzeczywistości ani takiego nie posiadają, podobnie jak ustalonej tożsamości. Nie można powiedzieć też, że wybierają czy narzucane im są różne identyfikacje, gdyż nie istnieje ja, które mogłoby inicjować lub poddawać się tym działaniom.

Opisaną wyżej rzeczywistość, w moim przekonaniu, skonceptualizowano w trybie modernistycznym i choć ujęcie to jest złożone, to zarazem klarownie i produktywnie opracowuje racjonalne i efektywne praktyki kapitalistyczne. Wszechstronność modernizmu (nie tylko językowego), w tym zdolność do artykułowania skomplikowanych problemów naukowych, jest rezultatem, jak dowodzą jego badacze $^{14}$, współpracy z odkryciami rewolucjonizującymi nowoczesną naukę od drugiej połowy XIX w. Wyjaśniają oni między innymi, że estetyka modernistyczna budowana była także po to, aby przedstawiać świat przy użyciu środków i wiedzy

\footnotetext{
13 J. Swianiewicz, Możliwość makrohistorii. Braudel, Wallerstein, Deleuze, Toruń-Warszawa 2014.

14 Zob. Th. Vargish, D.E. Mook, Inside Modernism. Relativity Theory, Cubism, Narrative, New Haven-London 1999, passim.
} 
wypracowanej np. przez fizykę ponewtonowską. Mówiąc w dużym skrócie, w realizmie przedmodernistycznym - podobnie jak świecie fizycznym Newtona - czas i przestrzeń to gotowe i niezależne pojemniki, w których działają bohaterowie i rozgrywa się akcja opowieści. W modernizmie - tak jak u Einsteina twierdzącego, że czas i przestrzeń nie mogą być traktowane jako niezależne od punktu odniesienia, z którego są obserwowane - dochodzi do zniesienia rozróżnienia na społecznie zobiektywizowaną rzeczywistość i partykularne pozycje obserwacyjne tych, którzy się w niej znajdują. W rezultacie zdarzenia nie mają wyraźnych granic przestrzennych i czasowych, a rzeczywistość dzieli się na wiele działających jednocześnie pól (gdyż różne procesy w niej zachodzące mają w dużym stopniu autonomiczną temporalność i rządzą się w pewnej mierze niezależnymi zasadami). Stosunki między wspomnianymi polami nie przybierają charakteru hierarchicznego i nie można wskazać jednego centrum, siły czy sensu napędzającego tę dynamiczną całość i nadającego jej kierunek. Nie można więc sformułować jednej, spójnej, pełnej sensu narracji o jej funkcjonowaniu w czasie ${ }^{15}$.

Modernistyczne przedstawienie rzeczywistości może oddawać nie tylko dezorientację wynikającą z przytłoczenia ofiary nadmiernie złożoną i obcą jej kompetencjom wiedzą, z powodu poddania terrorowi i z partykularnej perspektywy jej pozycji, która uniemożliwia jej dostrzeżenie racjonalnego porządku rzeczywistości. Sprawnie służy również próbie ujęcia nowego dziania się skoncentrowanej na sferze sprawcy, ale też postronnego czy pomocnika śmierci. Próba zdefiniowania ich w trybie realizmu przedmodernistycznego uprościłaby ich wewnętrzną złożoność czy po prostu mówiłaby o innej rzeczywistości.

Dodam jeszcze, że moim zdaniem, synchroniczny i wieloperspektywiczny język opisu systemów, struktur czy maszyn społecznych rezygnujący z budowania prostych i jednostronnych relacji między zjawiskami, linearnej chronologii z wydarzeniami osadzonymi punktowo na osi czasu oraz aktorami ludzkimi o klarownej tożsamości i jasnych motywacjach działania, wypracowuje od prawie 100 lat współczesna historiografia, ze szkołą Annales, a później angloamerykańską historią kulturową na czele. White, co może zdumiewać, nie komentuje tej historiografii. Jeśli omawia

15 Przywołany tu przykład wywołuje ważne pytanie: czy zdarzenie modernistyczne to składowa tylko najnowszej historii, czy pojawiało się już we wcześniejszych epokach? Pytanie to nie zostało podjęte przez White’a. Marksistowska tradycja myślenia, z której korzystają wspomniani autorzy, podpowiada, że zdarzenia modernistyczne mogły mieć miejsce w przeszłości, gdyż elementy różnych formacji społecznych, w tym kapitalizmu, były jednocześnie obecne w dawnych epokach. O obliczu danego okresu decydowała dominująca w nim formacja. 
teksty historyków - co robi rzadko - to tylko takie, które łatwo może skrytykować z zajmowanych przez siebie pozycji teoretycznych. Przedmiotem jego analizy bywają raczej prace filozoficzne, powieści modernistyczne i postmodernistyczne, ewentualnie kanon dziewiętnastowiecznej historiografii, a jedyną pracą historyczną, której poświęcił więcej uwagi jest książka Saula Friedlandera Czas eksterminacji ${ }^{16}$.

Brak wyraźnego stwierdzenia ze strony White’a, że we współczesnej historiografii rozpoznaje mniej lub bardziej konsekwentne czy trafne realizacje swojego postulatu budowania modernistycznej historiografii tworzy wrażenie, że wypowiedź modernistyczna jest niezwykłym dokonaniem zarezerwowanym jedynie dla wybranej grupy mistrzów języka. Wzmacnia tym samym podział na pracę artystyczną i nieartystyczną, a także artystyczną i naukową, których krytyka była ważnym elementem jego własnej refleksji teoretycznej. Ponadto generuje mylną sugestię, że modernizm jest niezdolny do trafnego ujęcia racjonalnych mechanizmów społecznych i praktyk zastosowania zaawansowanych technologii w wykonywaniu władzy.

Zdarzenia modernistyczne niosą destrukcję i cierpienie, a tym samym budzą potrzebę przywrócenia sprawiedliwości poprzez zidentyfikowanie ofiar oraz sprawców i ich czynów. Pełna, jasna i jednoznaczna dystrybucja ról, nawet jeśli się wydaje etycznie słuszna, jest jednak trudna do przeprowadzenia. Trafnie problem ten eksponuje wypowiedź modernistyczna, która wychodzi poza porządek fundowany na opozycjach i pozwala opracować złożoną problematykę sprawczości uczestników współczesnej historii. Nie są to bowiem w pełni świadome swoich działań i warunków, w których je przeprowadzają, racjonalne jednostki lub procesy o czytelnych, konsekwentnie pracujących mechanizmach, które łatwo poddają się ocenie moralnej. Historiografia służąca społeczeństwu - wracam tu do sugestii White - dostarcza analiz i interpretacji tego, co mu się przytrafia, w tym omówień działania współtworzących je jednostek, grup, sił, struktur, systemów. Obok formułowania ocen moralnych wiele wysiłku wkłada w ostrzeganie go przed dystopiami zagrażającymi dobru wspólnemu.

16 Pisał o tym Krzysztof Zamorski w odniesieniu do pisarstwa historycznego tworzonego w paradygmacie „historii jako nauki społecznej”, zob. K. Zamorski, Dziwna rzeczywistość. Wprowadzenie do ontologii historii, Kraków 2008, s. 131. Wspomniana praca Friedlandera to: S. Friedlander, Czas eksterminacji. Nazistowskie Niemcy i Żydzi 1939-1945, przeł. S. Kupisz, A.M. Nowak i K. Masłowski, Warszawa 2010. White omawia ją w artykule: H. White, Prawda historyczna, wyobcowanie i niedowierzanie, przeł. E. Wilczyńska, [w: ] tegoż, Przeszłość praktyczna, red. E. Domańska, Kraków 2014, s. 179-209; H. White, Historical Discourse and Literary Theory. On Saul Friedländer's Years of Extermination, [w:] Den Holocaust erzählen. Historiographie zwischen wissenschaftlicher Empirie und narrativer Kreativität, red. N. Frei, W. Kansteiner, Göttingen 2013, s. 51-78. 
dr Jakub Muchowski

Instytut Historii, Wydział Historyczny

Uniwersytet Jagielloński

ul. Gołębia 13, 31-007 Kraków

jakub.muchowski@uj.edu.pl 